\title{
Myeloperoxidase-Antineutrophil Cytoplasmic Antibody-Negative Microscopic Polyangiitis with Pulmonary Haemorrhage and IgA Nephropathy
}

\author{
Yuichiro Endo Haruka Minato Reiko Taki Mayumi Kato \\ Satoshi Kore-Eda Yoshiki Miyachi Miki Tanioka \\ Department of Dermatology, Graduate School of Medicine, Kyoto University, Kyoto, \\ Japan
}

\section{Key Words}

IgA nephropathy · Microscopic polyangiitis · Pulmonary haemorrhage

\begin{abstract}
Aim: To report a case of a patient with myeloperoxidase-antineutrophil cytoplasmic antibody (ANCA)-negative microscopic polyangiitis (MPA) and IgA nephropathy associated with severe pulmonary haemorrhage.

Case Report: A 59-year-old man presented with ANCA-negative systemic vasculitis accompanied by purpura, nephritis and pulmonary haemorrhage. A skin biopsy specimen revealed pandermal leucocytoclastic vasculitis without $\lg A$ deposition and a kidney biopsy showed mesangial nephritis with IgA deposition. Considering these findings, the patient was diagnosed as having MPA with IgA nephropathy.

Discussion: In most cases, MPA presents with rapidly progressive necrotizing glomerulonephritis and sometimes lung haemorrhage, while IgA nephropathy is less common among MPA cases. As recent research suggested that in MPA immunoglobulin deposition in the kidney may be an exacerbating factor for renal dysfunction and poor prognosis, close observation is required in these cases.
\end{abstract}

\section{Introduction}

Microscopic polyangiitis (MPA) is a myeloperoxidase-antineutrophil cytoplasmic antibody (MPO-ANCA)-associated systemic small-vessel vasculitis characterized by rapidly progressive necrotizing glomerulonephritis and sometimes lung haemorrhage [1]. However, to the best of our knowledge, IgA nephropathy is less common in MPA. Here, 


\begin{tabular}{l|l|l|l}
$\begin{array}{c}\text { Case Reports in } \\
\text { Demmatoloyy }\end{array}$ & $\begin{array}{l}\text { Case Rep Dermatol 2011;3:22-27 } \\
\text { DOI: } 10.1159 / 000324422\end{array}$ & $\begin{array}{l}\text { Published online: } \\
\text { February 5, 2011 }\end{array}$ & $\begin{array}{l}\text { O 2011 S. Karger AG, Basel } \\
\text { ISSN 1662-6567 } \\
\text { www.karger.com/cde }\end{array}$ \\
\hline
\end{tabular}

we present the case of a patient with MPO-ANCA-negative systemic vasculitis associated with pulmonary haemorrhage $(\mathrm{PH})$ and IgA nephropathy.

\section{Case Report}

A 59-year-old man was admitted to our hospital complaining of fever, palpable purpura, retiform ulcer, paraesthesia, joint pain of the knees and muscle pain of the lower extremities. Two months before admission, he had noticed paraesthesia and purpura spreading from the ankles to both the thighs after having taken a walk in the forest. The purpuric lesions soon progressed to skin ulcers (fig. 1). The patient did not experience any upper respiratory symptoms except for chronic tonsillitis. As trombiculiasis or vasculitis had been suspected in another hospital, minocycline and oral prednisolone 5-10 $\mathrm{mg}$ had been administered daily, but the response was poor. Fever and pitting oedema of the legs had gradually become apparent 4 days before admission. His previous medical history included untreated hypertension and gout. On admission, the blood pressure was $107 / 66 \mathrm{~mm} \mathrm{Hg}$ and the body temperature was $38.9^{\circ} \mathrm{C}$. Laboratory data showed a systemic inflammation (white blood cell count 11,400 cells $/ \mathrm{mm}^{3}$, C-reactive protein $30.2 \mathrm{mg} / \mathrm{dl}$ ) and renal dysfunction (proteinuria and gross haematuria). Serum IgA level was $632 \mathrm{mg} / \mathrm{dl}$ and anti-streptolysin O (ASO) $815 \mathrm{IU} / \mathrm{ml}$. Proteinase-3 and MPO-ANCA, anti-nuclear antibodies, anti-ds DNA, cryoglobulins, antiglomerular basal membrane antibodies, and anticardiolipin IgG antibodies were all negative. No significant increase in antibodies to chigger, hepatitis virus, Epstein-Barr virus, or cytomegalovirus was observed and blood culture was negative.

Histopathological examination of the purpura and peripheral lesion on the left lower limb revealed severe pandermal leucocytoclastic vasculitis with fibrinoid degeneration but no granuloma (fig. 2). On direct immunofluorescence of the skin lesion, complement deposits could only be found on the lumen of the affected vessels.

Six days after admission, dyspnoea and pink physaliform sputum suddenly appeared. Arterial blood gas analysis revealed hypoxaemia and a chest computed tomography demonstrated patchy consolidation and air bronchograms in both lung fields. On bronchoscopy, a haemorrhagic lavage was collected, containing erythrocytes, respiratory epithelial cells and neutrophils on cytological analysis. Results from a blood test showed that haemoglobin levels decreased by $2.2 \mathrm{~g} / \mathrm{dl}$. These data suggested alveolar haemorrhage. A renal biopsy that was additionally conducted to evaluate renal involvement revealed mild mesangial cellular proliferation and expansion as well as mesangial and diffuse IgA deposits (fig. 3). Crescents, however, were absent. These findings were compatible with IgA nephropathy rather than with necrotizing crescentic glomerulonephritis, which corresponds to rapidly progressive necrotizing glomerulonephritis and is usually seen in MPA. Although a skin biopsy from the lesion in the limbs was performed three times, IgA deposition in the skin was not identified at all. Since the diagnostic criteria of MPA were fulfilled [2], the above-mentioned clinicopathological findings collectively suggested ANCA-negative MPA with PH and IgA nephropathy.

The patient received intensive ventilatory support, and methylprednisolone pulse therapy $(1,000$ $\mathrm{mg} /$ day) was administered for 4 days, followed by methylprednisolone $125 \mathrm{mg} /$ day for 3 days and oral prednisolone. These treatments suppressed $\mathrm{PH}$ and proteinuria, but new purpura and haematuria developed. As the high level of ASO in this patient suggested that a streptococcal infection may have been an exacerbating factor, a tonsillectomy was performed; however, this procedure did not improve the patient's purpura. Addition of oral cyclosporine $150 \mathrm{mg} /$ day eventually controlled the clinical symptoms.

\section{Discussion}

We presented a case of ANCA-negative MPA with PH and IgA nephropathy. Differential diagnosis seems to be Henoch-Schönlein purpura (HSP). HSP is a smallvessel vasculitis in the upper layer of the dermis, which is triggered by IgA-related immune complexes [3]. Typically, about 50\% of the cases of HSP and IgA nephropathy are preceded by an upper respiratory tract infection, especially infection caused by 


\begin{tabular}{l|l|l|l}
$\begin{array}{c}\text { Case Reports in } \\
\text { Demmatoloyy }\end{array}$ & $\begin{array}{l}\text { Case Rep Dermatol 2011;3:22-27 } \\
\text { DOI: } 10.1159 / 000324422\end{array}$ & $\begin{array}{l}\text { Published online: } \\
\text { February 5, 2011 }\end{array}$ & $\begin{array}{l}\text { O 2011 S. Karger AG, Basel } \\
\text { ISSN 1662-6567 } \\
\text { www.karger.com/cde }\end{array}$ \\
\hline
\end{tabular}

streptococcal bacteria $[4,5]$. As ASO was high in our patient, we cannot deny the possibility that chronic tonsillitis might have played a role in triggering IgA nephritis and vasculitis. Palpable purpura and IgA-related nephropathy were indeed consistent with a finding of renal involvement of HSP. However, in comparison with MPA, in HSP PH is rare, occurring only in $1.2 \%$ of all cases $[1,6]$. Furthermore, the histopathological findings of the skin biopsies in our patient showed pandermal leucocytoclastic vasculitis without IgA deposition, which also contradicted the diagnosis of HSP [3]. Therefore, MPA with $\mathrm{PH}$ and IgA nephropathy was diagnosed, although an overlap of MPA and HSP was not completely deniable [7].

Recent studies indicated an association between MPA and IgA. For example, IgA ANCA has been considered a possible pathogen for HSP $[8,9]$. In addition, renal involvement in MPA has anecdotally been pauci-immune glomerulonephritis, which is characterized by mild or absent glomerular tuft staining for immunoglobulins and/or complements. However, some studies revealed that IgA deposition in the kidney can be observed in MPA [10-13]. Since immune complexes are thought to act synergistically with ANCA to produce more severe glomerulonephritis than is seen with ANCA or immune complexes alone [11], it may be possible that the prognosis of renal function was better in our case, because MPO-ANCA was absent. However, careful observation seems to be required in these cases.

\section{Disclosure Statement}

The authors have no conflicts of interest to declare.

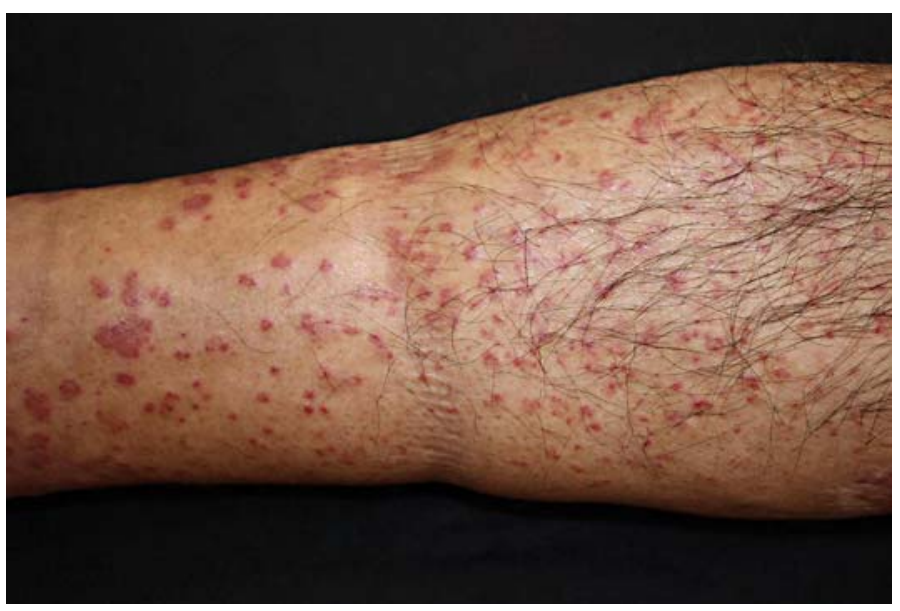

Fig. 1. Clinical features of lower extremities. Palpable purpura progressed, turning into blisters and forming retiform ulcers. 


\begin{tabular}{c|l|l|l}
$\begin{array}{c}\text { Case Reports in } \\
\text { Dermatology }\end{array}$ & $\begin{array}{l}\text { Case Rep Dermatol 2011;3:22-27 } \\
\text { DOI: } 10.1159 / 000324422\end{array}$ & $\begin{array}{l}\text { Published online: } \\
\text { February 5, 2011 }\end{array}$ & $\begin{array}{l}\text { O 2011 S. Karger AG, Basel } \\
\text { ISSN 1662-6567 } \\
\text { www.karger.com/cde }\end{array}$ \\
\hline
\end{tabular}

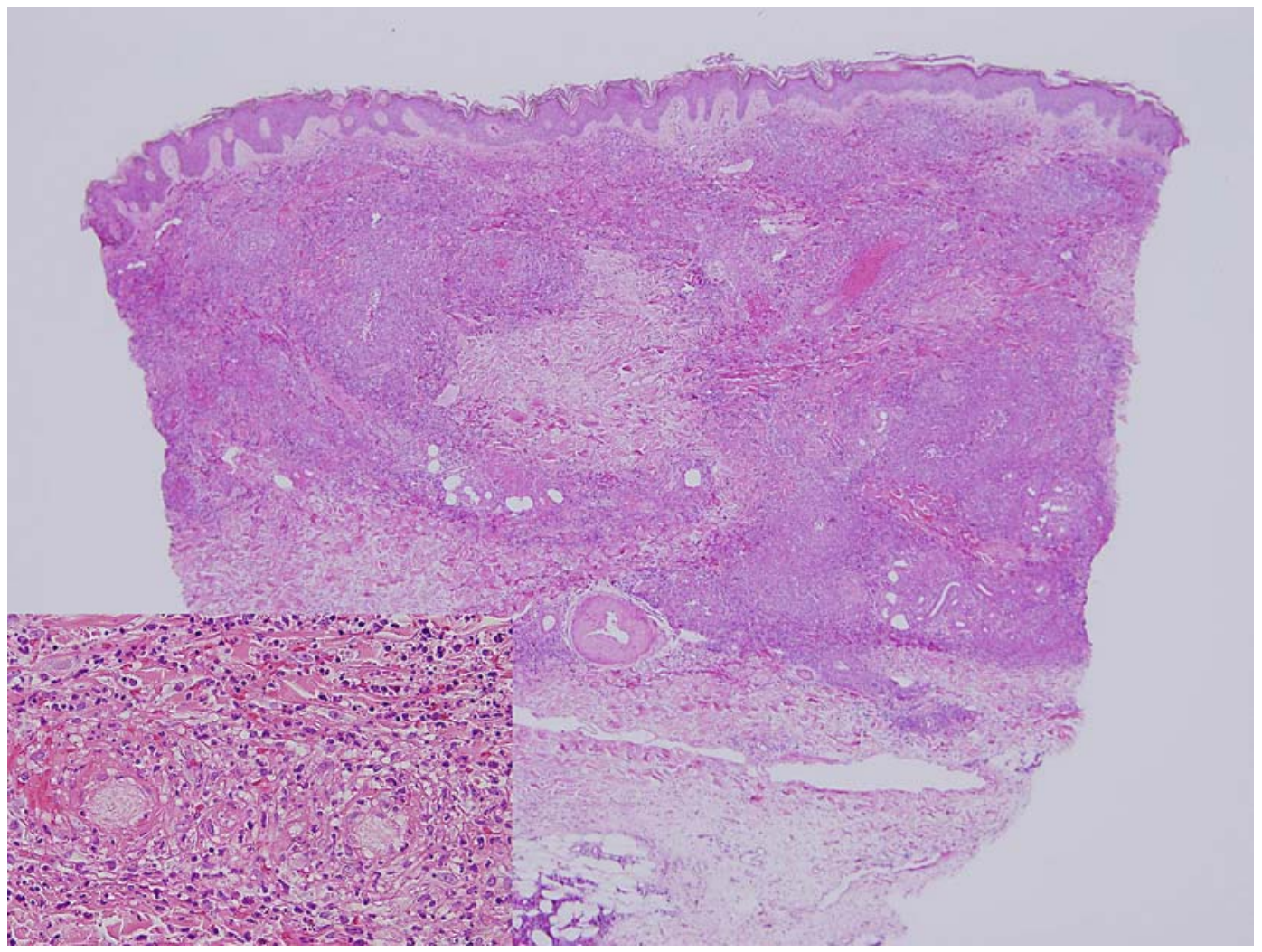

Fig. 2. Microscopic examination of palpable purpura. Severe pandermal leucocytoclastic vasculitis without granulation $(\mathrm{HE}$, original magnification $\times 40$; inset: $\times 400)$. 


\begin{tabular}{l|l|l|l}
$\begin{array}{l}\text { Cosse Reports in } \\
\text { Dermatology }\end{array}$ & $\begin{array}{l}\text { Case Rep Dermatol 2011;3:22-27 } \\
\text { DOI: } 10.1159 / 000324422\end{array}$ & $\begin{array}{l}\text { Published online: } \\
\text { February 5, 2011 }\end{array}$ & $\begin{array}{l}\text { O 2011 S. Karger AG, Basel } \\
\text { ISSN 1662-6567 } \\
\text { www.karger.com/cde }\end{array}$ \\
\hline
\end{tabular}

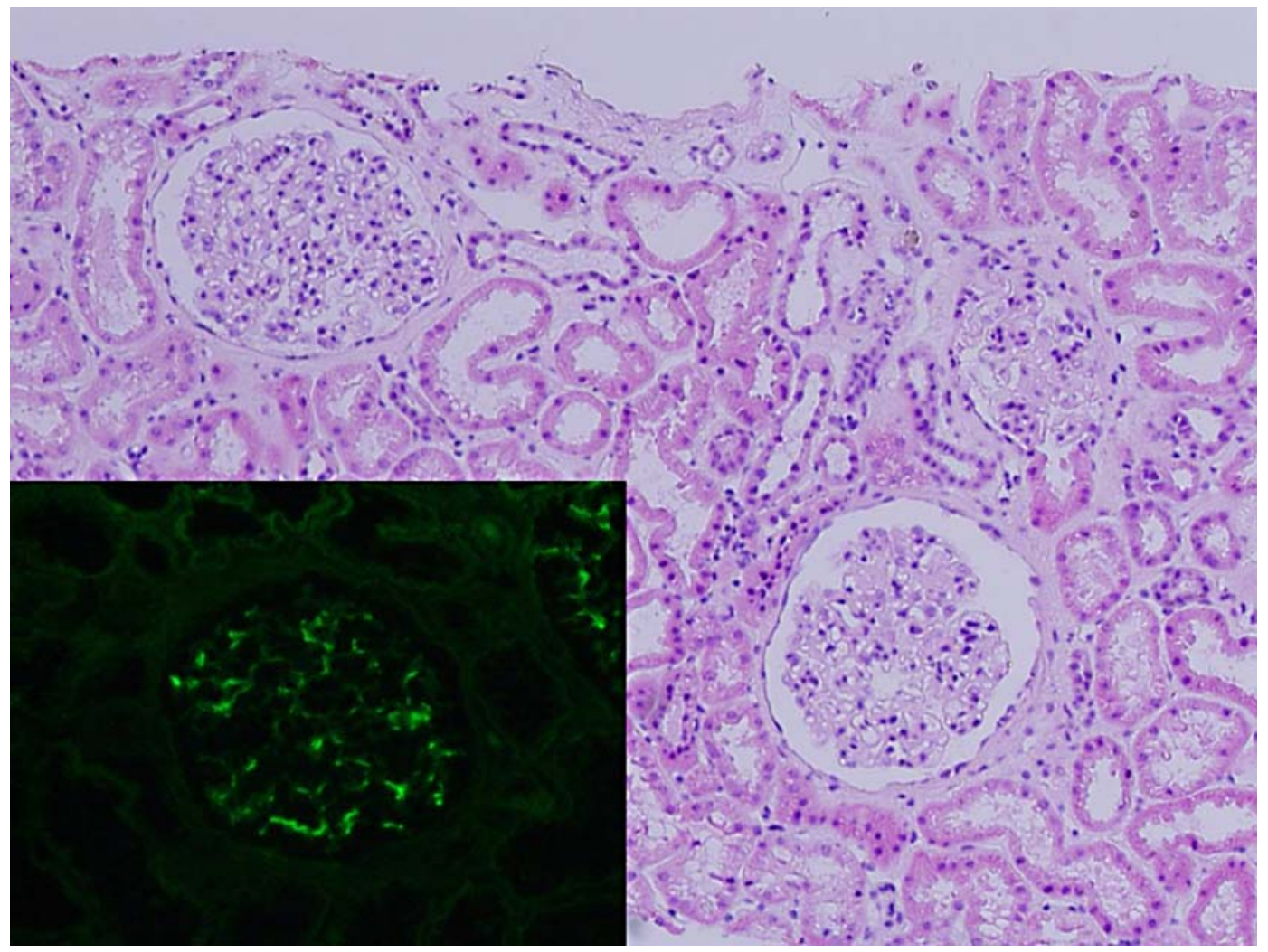

Fig. 3. Microscopic examination of the kidney biopsy specimen. Mild mesangial cellular proliferation and expansion. Mesangial and diffuse IgA deposits were observed and crescents were absent (HE, original magnification $\times 100$; inset: direct immunofluorescence $\times 100$ ). 


\section{References}

1 Guillevin L, Durand-Gasselin B, Cevallos R, et al: Microscopic polyangiitis: clinical and laboratory findings in eighty-five patients. Arthritis Rheum 1999;42:421-430.

2 Nakabayashi K, Hashimoto H: Microscopic polyangiitis; in Hashimoto H (ed): Clinical Manual for Vasculitis. Tokyo, Research Group of Intractable Vasculitis, Ministry of Health, Labor, and Welfare of Japan, 2002, pp 2426.

3 Carlson JA: The histological assessment of cutaneous vasculitis. Histopathology 2010;56:3-23.

4 Donadio JV, Grande JP: IgA nephropathy. N Engl J Med 2002;347:738-748.

5 Levy M, Broyer M, Arsan A, et al: Anaphylactoid purpura nephritis in childhood: natural history and immunopathology. Adv Nephrol Necker Hosp 1976;6:183-228.

6 Nadrous HF, Yu AC, Specks U, et al: Pulmonary involvement in Henoch-Schönlein purpura. Mayo Clin Proc 2004;79:1151-1157.

7 Nagasaka T, Miyamoto J, Ishibashi M, et al: MPO-ANCA- and IgA-positive systemic vasculitis: a possibly overlapping syndrome of microscopic polyangiitis and Henoch-Schoenlein purpura. J Cutan Pathol 2009;36:871-877.

8 Patterson CC, Ross P Jr, Pope-Harman AL, et al: Alpha-1 anti-trypsin deficiency and Henoch-Schönlein purpura associated with anti-neutrophil cytoplasmic and anti-endothelial cell antibodies of immunoglobulin-A isotype. J Cutan Pathol 2005;32:300-306.

-9 Ronda N, Esnault VL, Layward L, et al: Antineutrophil cytoplasm antibodies (ANCA) of IgA isotype in adult Henoch-Schönlein purpura. Clin Exp Immunol 1994;95:49-55.

10 Bantis C, Stangou M, Schlaugat C, et al: Is presence of ANCA in crescentic IgA nephropathy a coincidence or novel clinical entity? A case series. Am J Kidney Dis 2010;55:259-268.

11 Haas M, Eustace JA: Immune complex deposits in ANCA-associated crescentic glomerulonephritis: a study of 126 cases. Kidney Int 2004;65:2145-2152.

12 Neumann I, Regele H, Kain R, et al: Glomerular immune deposits are associated with increased proteinuria in patients with ANCA-associated crescentic nephritis. Nephrol Dial Transplant 2003;18:524-531.

13 Yu F, Chen M, Wang SX, et al: Clinical and pathological characteristics and outcomes of Chinese patients with primary anti-neutrophil cytoplasmic antibodies-associated systemic vasculitis with immune complex deposition in kidney. Nephrology (Carlton) 2007;12:74-80. 